\begin{tabular}{|c|c|c|}
\hline $\begin{array}{l}\text { FATIH } \\
\text { SULTAN } \\
\text { MEHMET } \\
\text { VAKK UNIIVERSIESI } \\
2010\end{array}$ & $\begin{array}{l}\text { FSM İlmî Araştırmalar Insan ve Toplum Bilimleri Dergisi } \\
\text { FSM Scholarly Studies Journal of Humanities and Social Sciences } \\
\text { Sayı/Number } 14 \text { Yıl/Year } 2019 \text { Güz/Autumn } \\
\text { (C2019 Fatih Sultan Mehmet Vakıf Üniversitesi }\end{array}$ & 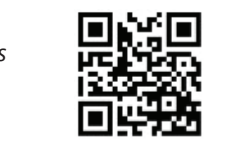 \\
\hline DOI: & http://dergipark.org.tr/fsmia & http://dergi.fsm.edu.tr \\
\hline Araştırma Makalesi / Research Article & Geliş Tarihi / Received: 10.03.2019 Kabul Tarihi / Accepted: 30.09 .2019 & FSMIAD, 2019; (14): 461-480 \\
\hline
\end{tabular}

\title{
Sosyal Koruma Açısından İslâm'da Yoksul ve Miskinlerin Yeri
}

Aynur Yumurtaci*

\section{$\ddot{O} z$}

Yoksulluk geçmişten günümüze pek çok araştırmacının üzerinde önemle durduğu bir konu olmuştur. Ancak yoksulluk genellikle tek boyut üzerinden düşünülmüş ve yoksulluğu önleme amaçlı üretilen politikalar da tek boyutlu olmuştur. Oysa yoksulluğun farklı ve özel anlam içeren bir boyutu da bulunmaktadır. Bu boyut miskinliktir. Miskinlerin, yoksulluğun görünmeyen bir yüzü olduğunu bilmek ve sosyal koruma kapsamına nasıl alınacağını tespit etmek sosyal dengelerin sağlanması bakımından önemlidir. Bu çalışmada İslâm'ın korunmasını emrettiği özel gruplardan biri olan gizli yoksullara (miskinlere) yönelik sosyal korumanın nasıl ve hangi araçlarla sağlanabileceği sorularına yanıt aranmaktadır. Bu arayışta sahip olduğu mükemmel potansiyel ile zekât müessesesinin önemi vurgulanmaktadır.

Anahtar Kelimeler: İslâm, miskin, yoksul, sosyal koruma, sosyal yardım.

* $\quad$ Dr., İstanbul Üniversitesi Sosyal Bilimler Enstitüsü Çalışma Ekonomisi ve Endüstri İlişkileri Anabilim Dal, İstanbul/Türkiye, aynur.yumurtaci@gmail.com, orcid.org/0000-0003-02775750 


\title{
The Place of Poor and Unseen Poor in Islam in Terms of Social Protection
}

\begin{abstract}
Poverty has been a topic that was strongly focussed by many researchers from past to present. However, poverty has usually been thought out at one dimension and policies, produced for aiming to prevent poverty, have also been one-dimensional. But, there is also a dimension that contains different and special meaning of poverty. This dimension is the unseen-poor. To know the unseen poor as being an invisible face of poverty and how to detect them into social protection is important in terms of providing social balances. In this study, looking for answers to the questions about how and which tools provide to social protection for unseen poor as a particular group that ordered the protection of Islam. The importance of Alms (Zekat) institutions that have excellent potential in this quest are highlighted.
\end{abstract}

Keywords: Islam, unseen/silent poor, poor, social protection, social assistance. 


\section{Giriş}

Günümüzde yoksul ile miskin arasındaki farkın yeterince bilinmediği anlaşılmaktadır. Yoksullar ile miskinleri, maddî yetersizlik açısından aynı kategoride ele almak mümkün olduğu halde miskinler hakkında toplumda olumsuz bir alg1 gözlemlenmektedir. Bu durumun temel sebebinin menfi yönde anlam kaymasina bağl1 olarak toplumun ekseriyetinin gizli yoksullar olarak nitelendirilen miskinleri daha çok uyuşuk, tembel ve(ya) hiçbir işe yaramaz insanlar olarak görmelerinden kaynaklandığı düşünülmektedir. Hâlbuki Kur'an-1 Kerim'de fakirlerden hemen sonra gizli yoksul konumundaki miskinlerin de zekâttan yararlanma hakkına sahip olanlar arasında bulunduğu zikredilmektedir. İlgili ayet şu şekildedir:

Sadakalar (zekâtlar), Allah'tan bir farz olarak ancak fakirler, düşkünler, zekât toplayan memurlar, kalpleri İslam'a ısındırılacak olanlarla (özgürlüğ̈̈ne kavuşturulacak) köleler, borçlular, Allah yolunda cihad edenler ve yolda kalmış yolcular içindir. Allah hakkıyla bilendir, hüküm ve hikmet sahibidir. ${ }^{1}$

Ayette geçen fakir ve düşkün ifadeleri ile özellikle gizli yoksul olarak nitelendirilen miskinlere işaret edildiği açıkça görülmektedir. ${ }^{2}$

Dolayısı ile yoksulların olduğu gibi, miskinlerin de sosyal korumaya dâhil edilmesi konusu Kur'an-1 Kerim'de ortaya konmuştur. Bu durumda muhtaçlık kapsamında değerlendirilen miskinliği ve miskinlerin taşıdığı özellikleri bilerek onlara yaklaşmaya çalışmak ve onlar için sosyal koruma politikaları belirlemek ve geliştirmek gerekmektedir.

$\mathrm{Bu}$ çalışma ile hem geleneksel hem de modern döneme ilişkin miskinlik olgusunun ne olduğunun, nasıl anlaşıldığının, hangi açılardan yoksulluk ile farkl1lık gösterdiğinin değerlendirilmesi amaçlanmaktadır. Çalışma, toplumda oluşan genel algının aksine miskinlik ve yoksulluğun aynı durumlar olmadığının ortaya konması bakımından önem taşımaktadır.

\section{İslam'da Yoksullar ve Sosyal Koruma Yöntemleri}

Yoksulluk (fakirlik, muhtaçlık) ve yoksul (fakir, yardıma muhtaç) kavramlarını farklı kriterler bakımından ele almak ve farklı şekillerde tanımlamak mümkündür. En geniş yaklaşımla yoksulluk ve yoksul ile ilgili tanımlar ince-

1 Kur'an-1 Kerim, Tevbe (9): 60

2 Ahmet Ekşi, “Hz. Ömer'in "Miskin” Kavramıyla Zekât Uygulamalarına Getirdiği Açılım”, Mart 2019, (http://akademikpersonel.kocaeli.edu.tr/ahmet.eksi/toplanti/ahmet.eksi02.10.2017_09.18.13toplanti.pdf), s.2; Beytullah Aktaş, “Zekâtın Harcama Kalemlerinden Fakir ve Miskin Kavramlarının Kur'an Bağlamında Yeniden Tanımlanması”, Harran Üniversitesi Illahiyat Fakültesi Dergisi, y1l 20, sayı 33, Ocak-Haziran 2015, s.107. 
lendiğinde; temel ve zorunlu gereksinimlerini karşılayamama, kazanç ve gelirden mahrum olmaya bağlı olarak mutlak ya da nispi bakımdan yetersiz olma durumu yoksulluk, buna bağlı olarak mutlak anlamda veya göreceli olarak maddî yetersizlikler içinde yaşayan yardıma muhtaç insanlar da yoksullar olarak tanımlanmaktadır. ${ }^{3}$

Yoksulluk konusunda yapılmış araştırmalara göre, yoksulluğun temel kaynakları; içinde bulunulan ekonomik sistem ve bireylerin kendi zaafları olarak açıklanmaktadır. Bu tabloda genel manada insanlığın önleyemeyeceği bir yoksulluk yok gibi görünmektedir. ${ }^{4} \mathrm{Bu}$ durum yoksulluğun sadece görünen ve tek bir yüzünü oluşturmaktadır. Oysaki yoksulluk, göründüğünden daha karmaşık bir olgudur. Örneğin; bazı yoksulların, yaşayabilecek bir miktar malı olabileceği gibi bütünüyle her türlü maldan da yoksun olan kimseler olduğu görülmektedir. İslâmi bir yaklaşımla yoksullar, nisaba malik olmamakla beraber az veya çok az bir şeylere sahip olduğu halde yine de asgari hayat standardının altında kalan maddî yetersizlik durumlarına göre az veya çok yardıma muhtaç kişilerdir. ${ }^{5}$

Bu bilgilerden yola çıkarak, yoksulları günümüzün sosyo-ekonomik şartları doğrultusunda değerlendirmek mümkündür. İşgücü sahibi olup emek piyasasında çalışmak istedikleri halde sırf iş bulamadıkları için gelirden mahrum kalan işsizler, mutlak yoksulluğa itilebilmektedir. Emek piyasasında çalıştı̆̆ 1 halde, yeterince ücret alamadığından dolayı geçinemeyen işçiler ve aile fertleri de nispi yoksullardan sayılmaktadır. Yaşlılık veya engellilik gibi bazı fizikî-fizyolojik sebeplerden dolayı işgücü niteliği taşıyamayan ve dolayısıyla emek piyasasında çalışamayan insanlar da yoksul olabilmektedir. Kısacası işgücü niteliği taşısın veya taşımasın işsiz veya gayri ihtiyari olarak gelirsiz durumda olan bu yoksul kesime geçinecek kadar gelir transferinde bulunmak, sosyal devletler için önemli bir görevdir. Ancak bu konuda hatırda tutulması gereken önemli bir durum da bulunmaktadır. İşgücü niteliği taşıyan işsiz yoksullara iş imkânı sağlamak suretiyle onların geçimlerini temin etmelerini sağlamanın, onlara sürekli olarak sosyal transferde (kamusal sosyal yardımda veya zekât yardımında) bulunmaktan daha faydalı bir yöntem olacağı da dikkatlerden uzaklaştırılmamalıdır. Ancak kişinin bazen tam, bazen de kısmî olarak çalışma gücünün olmaması durumunda (çocuk, yaşl1, güçsüz, bakıma muhtaç gruplar vb.) sosyal transferlerin mutlak surette dev-

3 Ali Seyyar, Sosyal Siyaset Terimleri Ansiklopedik Sözlük, İstanbul, Beta Yayınları, 2002, s.171.

4 Osman Eyüpoğlu - Muhittin Düzenli, "Yoksulluk ve Dini Hayat”, Uluslararası Orta Asya Sempozyumu Bildiriler Kitabı Göç, Yoksulluk ve Kimlik, 17-20 Nisan 2018, Bişkek, Kırgızistan-Türkiye Manas Üniversitesi Yayınları, 2018, s.284.

5 Muhammed Ali Es-Sâbûnî, Safvetü t-Tefâsîr, çev. Nedim Yılmaz, Sadreddin Gümüş, c. 2, İstanbul, Ensar Yayınları, Ağustos, 2012, s.474. 
reye sokulması gereklilik içermektedir. Dolayısıyla hangi sebepten dolayı olursa olsun maddî yoksulluk, İslâm'a göre hem sosyo-ekonomik, hem de manevî bir risktir. Böyle bir yoksulluk, insanı sefalete ve açlığa sevk edebileceği gibi hem Allah'a karşı kulluk görevini unutturabilmekte, hem de toplumsal ahlâk açısından sosyal sapkınlıklara da itebilmektedir. Modern dönem sosyologları bu durumu, yoksulluk kültürü ${ }^{6}$ kavramı ile açıklama gayreti içindedirler.

Bu konu ile ilgili olarak, maddî yoksulluğun kişiyi küfre ve manevî sapkınlığa götürebileceğini ve fitnelere (toplumsal çalkantılara) sebebiyet verebileceğini bizzat Hz. Peygamber dillendirmiştir. Nitekim bir seferinde Hz. Peygamber, Allah'ım, yoksulluktan ve küfürden Sana siğınırım. diye dua edince, bir adam; Íkisini birbirine denk mi kabul ediyorsun? mealinde bir soru yöneltmiştir. Bunun üzerine Hz. Peygamber, evet cevabını vermiştir. ${ }^{7}$

Bunun ötesinde Hz. Peygamber, maddî yoksulluğun açacağı manevî tehlikeleri bildiği için, yardım istemek maksadıyla kendisine gelen yoksulların ihtiyaçlarını bazen de beytü'l-mal (zekât fonu) kaynaklarından gidermiştir. Beytü'l-malda yeterince kaynak olmadığı dönemlerde ise ya kendi imkânlarıyla ya da zengin sahabilerin desteği ile yoksullara infakta bulunmuştur. Görüldüğü üzere asr-1 saadette yaşamış olan yoksullar, maddî sıkıntılarını gizlemeden taleplerini doğruca Hz. Peygambere iletebilmişler, Hz. Peygamber de yoksul kişilerin psiko-sosyal veya fizikî durumlarına göre maddî ve manevî destekte bulunmuştur.

$\mathrm{Bu}$ durumda yukarıdaki örneklerde de görüldüğü gibi geçmişten günümüze muhtaç durumda olan yoksulların himaye altına alınması, kendilerine maddî korumanın dışında mânevi desteğin de sağlanması ile sosyal adalet (gelirin adaletli dağılımı açısından) sağlandığı gibi sosyal bütünleşme de geliştirilebilmiştir. Böylelikle muhtaç durumda olan yoksullara sağlanan yardımlarla hem yoksulluğun kişi ve toplum üzerindeki olumsuz etkileri azaltılmış, hem de sosyal sorumluluğu yerine getirmenin huzuru sağlanmıştır. Buradan hareketle yoksullara yönelik sosyal korumanın sadece belirli bir dönem için değil insanın var olduğu her dönemde, her yerde ve her zaman önem taşıdığı görülmektedir.

6 Yoksulluk kültürü kavramı ilk kez (1959) Amerikalı antropolog Oscar Lewis tarafından kullanılmış olup, kavram ile yoksulluğun kuşaktan kuşağa geçen bir kültür ve yardım programlarına bağımlı hâle gelerek, çalışamama durumu olarak ifade edildiği görülmektedir. Ancak bu durum ekonomik nedenlere dayanmaktan çok psikolojik kabullenişi ve ne yapılırsa yapılsın yoksulluktan kaçılamayacağı yönündeki genel kanaati ortaya koymaktadır Bkz. Gamze Aksan, "Yoksulluk ve Yoksulluk Kültürünün Toplumsal Görünümleri”, Selçuk Üniversitesi Sosyal Bilimler Enstitüsü Dergisi, say1 27, 2012, s. 9.

7 Ebu Davud, Sünen-i Ebu Davud, İstanbul, Şamil Yayınları, 2009, s.101. 


\section{İslâm'da Miskinler ve Sosyal Koruma Yöntemleri}

Miskin kavramı köken olarak Arapçada "sükûnet" şeklinde ifade edilen kelimeden türemiştir. Yani miskin bir şeyin hareket ettikten sonra sabit kalması, durması şeklinde ifade edilmiştir. İbni Manzur ise miskini yeteri kadar ya da hiç malı olmayan zayıf bir kimse olarak açıklamaktadır. Kur'an-1 Kerim'de tekil boyutu ile 11 yerde, çoğul boyutu olarak da (mesâkîn) 12 yerde miskinlere işaret edilmektedir. ${ }^{8} \mathrm{Bu}$ ayetlerden ikisi şu şekildedir:

Akrabaya, yoksula ve yolda kalmıs yolcuya haklarını ver, fakat saçıp savurma. ${ }^{9}$

Öyle ise akrabaya, yoksula ve yolcuya hakkını ver. Bu, Allah'ın hoşnutluğunu kazanmak isteyenler için daha hayırlıdır. Işste onlar kurtuluşa erenlerdir. ${ }^{10}$

$\mathrm{Bu}$ kapsamda gizli yoksullar olarak ifade edilen miskinlere sosyal yardimda bulunmanın bir lütuf olmadığı Kur'an-1 Kerim'de de vurgulanmış olup, bu yardımın zorunlu bir toplumsal ve(ya) kamusal görev olduğuna işaret edilmiştir. Dolayısıyla miskinlerin kamusal sosyal yardımlardan yararlanabilmeleri netice itibariyle bir sosyal hak olarak görülmelidir. Buna bağlı olarak korunmaya muhtaç tüm sosyal kesimlere (korunmaya muhtaç gruplar olarak miskinler de bu grupta değerlendirilmelidir) yapılacak yardımlar ve iyilikler, Kur'an-1 Kerim'de sık sık hatırlatılmaktadır.

Maddî-manevî destek görmesi gerekenler arasında miskinlerin de anılması ile bu sosyal kesimin önemine adeta vurgu yapılmaktadır. Klâsik kaynaklarda tarif edilen miskinler bazen sağlıklı da olmakla birlikte, herhangi bir işleri bulunmaması sebebi ile gelire sahip olmayan, günlük iaşelerini temin etmede bile oldukça zorlanan, fakat içerisinde bulundukları bu durumu gizleyen, ayrıca utandıkları için etraflarından yardım talep edemeyen gerçek manada muhtaç insanlardır. ${ }^{11}$

Yoksulların belirli bir düzeyde mala bile sahip olabildiği gözlenirken, miskinler adeta hayatlarını sürdürmekte bile güçlük çeken kişiler olarak tanımlanmaktadır. Yani miskin yoksulluğun görünmeyen yüzü olarak da düşünülmektedir. ${ }^{12} \mathrm{Bu}$ durumda esas nokta hem yoksulun, hem de miskinin "İslami Sosyal Politikalar"

8 İslâm Ansiklopedisi, c. 30, İstanbul, Türkiye Diyanet Vakfi, 2005, s. 183; Aktaş, a.g.e. s.109; Ekşi, a.g.e. s.2.

9 Kur'an-ı Kerim, İsrâ (17): 26.

10 Kur'an-ı Kerim, Rûm (30): 38.

11 Ali Seyyar, Ahlak Terimleri (Ansiklopedik Sözlük), İstanbul, Beta Yayınları, 2003, s. 298.

12 Cemal Ağırman, "Yoksullukla Mücadelede Ahlaki ve Dini Eylem Olarak İnfakın Rolü”, Yoksulluk Sempozyumu, ed. Ahmet Emre Bilgili, İbrahim Altan, İstanbul, Deniz Feneri Yayınları, 2003, s.327-343. 
bağlamında sosyal korumaya ihtiyacı olduğudur. Yani her iki grup için de maddi bağlamda ihtiyaç sahibi olma durumu vardır.

Farklı mezhepler bağlamında da miskinlerin mi yoksulların mı daha ihtiyaç sahibi olduğu konusunda görüş farklılıkları ortaya çıkmıştır. Hanefiler için miskinler yoksullara göre daha muhtaç durumda iken, Şafiiler yoksulların miskinlere kıyasla daha muhtaç durumda olduklarını savunmaktadırlar. ${ }^{13}$

$\mathrm{Bu}$ durumda aynı yoksullar gibi korunmaya muhtaç gruplar arasında zikredilen gizli yoksulların (miskinlerin) özel profillerini teşhis etmedikçe yoksullara yapılacak sosyal yardım konseptlerinin ve uygulamalarının miskinlere de uygulanabileceğini kabul etmek tutarlı gözükmektedir. Ancak böyle bir yaklaşımın Kur'an-1 Kerim'in ve Sünnetin ruhuna aykırı olacağını tahmin etmek de herhalde güç olmayacaktır. Mademki yoksul ve korunmaya muhtaç oldukları kolaylıkla anlaşılabilen miskinler ayrıca zikrediliyor o halde miskinlerin diğer yoksullardan farklı olarak hangi özellikleri taşıdıklarını ortaya koymak gerekmektedir ta ki miskinlere uygun sosyal koruma uygulamaları geliştirilebilsin.

Aşağıda açıklanan miskinlere ilişkin bu özellikler vasıtası ile miskinleri yoksullardan ayırt etmek daha da kolaylaşacağ 1 gibi bu kapsamda miskinlere yönelik etkin sosyal koruma yöntemlerini belirlemek de kolaylaşacaktır.

\section{Dilenmekten Hayâ Eden Müslüman Yoksullar Olarak Miskinler}

Kur'an-1 Kerim, yüzsuyu dökerek halktan bir şey istemeyen onurlu fakirleri şu şekilde övmektedir:

(Sadakalar) kendilerini Allah yoluna adayan, yeryüzünde dolaşmaya güç yetiremeyen fakirler içindir. Iffetlerinden dolayı (dilenmedikleri için), bilmeyen onları zengin sanır. Sen onlarl yüzlerinden tanırsın. Insanlardan arsızca (bir şey) istemezler. Siz hayır olarak ne verirseniz, şüphesiz Allah onu bilir. ${ }^{14}$

Kur'an-1 Kerim terminolojisinde miskinler (yukarıdaki ayet ile de ifade edilen yeryüzünde dolaşmaya güç yetiremeyen fakirler "miskin fakirler"), kendini Allah yoluna adama, şeref, dilenmeme, özveri, durumunu başkalarına bildirmekten utanma gibi ahlâkî erdemler ve sosyo-kültürel özellikler taşıyan şahsiyetli insanlardır. Bu bağlamda miskinlerin başlıca özellikleri maddi yetersizliklerini dile getirmemeleri ve(ya) doğrudan göstermemeleri ve herhangi bir merciden yardım talep etmemeleridir. Diğer bir ifadeyle karakterleri ve mizaçlan gereği miskinler, yoksulluklarını kimseye yük olmak istemedikleri için gizlemektedirler. $\mathrm{Bu}$

13 Faruk Taşc1, Sosyal Politika Ahlâkı, Ankara, Nobel Yayıncılık, 2012, s. 139-141.

14 Kur'an-ı Kerim, Bakara (2): 273. 
yönüyle miskinler, bugünün yoksulluk araştırmalarında genelde gizli veya sessiz yoksullar olarak bilinen fakirler kapsamına girmektedirler. Tasavvufta da fakirler, Allah'tan başka hiçbir şeye muhtaç olmayan, yoksul oldukları halde kendi halleriyle memnun olan züht ve takva içinde yaşayan kanaat sahibi insanlar olarak tanımlanmaktadır. Tasavvufta fakr, "farzları yerine getirmekten aciz kalma korkusu olmadıkça rızık isteğinde bulunmamak", her şeyi Allah'a irca etmek, her şeyin gerçek sahibinin Allah olduğunu idrak etmektir. ${ }^{15}$

Sûfîler, Allah'tan fazlını ve ihsanını talep ettikleri için, ya dünyalık adına hiçbir şeye sahip değildir ya da dünyalık adına herhangi bir şey arzu etmemektedirler. Sûfîlerin mal sahibi olmak istememelerinin ve mala düşkün olmamalarının iki önemli sebebi vardır. Birincisi, mal helal da olsa bunun hesabının zor verileceği endişesi, diğeri de dünya malının ibadetleri gölgeleyebileceği ve ihlâsa zarar verebileceği korkusudur. ${ }^{16}$

Hz. Peygamber de bu doğrultuda miskinlerin haddizatında güzel ahlâk sahibi fakirler olduklarını şu hadis-i şeriflerinde beyan etmiştir: Miskin, kendini bir-iki hurmanın, bir-iki lokmanın geri çevirdiği (kapı kapı dolaşarak) dilenen bir insan değildir. Miskin, ihtiyaç içerisinde bulunduğu halde istemeyen, durumu halk tarafindan bilinmediği için yardım edilmeyen, iffet ve nezâfet (temizlik) sahibi mümindir. ${ }^{17} \mathrm{Bu}$ durumda miskin, ihtiyacını giderecek bir şey bulamayan ve yaşadığı muhtaçlık halini fark edip kendisine yardım edecek biri çıkmayan, içinde bulunduğu zorluk halinde bile kimseden bir şey istemeyen/isteyemeyen bir kişidir. Yani miskinler, yardıma muhtaçlık durumları olmasına rağmen bunu açıkça belli etmeyen, yardım dahi isteyemeyen bir grup özel yoksullar/fakirlerdir.

Kısaca, miskin fakir yerine fakir de miskin yerine kullanılsa da biz utanıp isteyemeyen yoksul bireye miskin demekteyiz. Tek başına miskin veya fakir kavramını kullanmak bu yüzden hatalı anlamalara sebep olabilir. Çare olarak dilenmeye hayâ eden miskin veya dilenmeye utanan fakir demek mümkündür.

\section{İslâm Toplumunun Gayrimüslim Yoksulları Olarak Miskinler}

Kur'an-1 Kerim, sadece Müslüman yoksullara değil, zimmî statüsünde olan gayrimüslim yoksullara da genel anlamda sadakanın, dar anlamda zekâtın veri-

15 Hayrani Altıntaş, Tasavvuf Tarihi, Ankara, Ankara Üniversitesi İlahiyat Fakültesi Yayınları, 1991, s. 124.

16 Molla Camî, Evliya Menkıbeleri, (Nefahat'ül Üns Min Hadarat'il Kudüs), sadeleştiren Abdulkadir Akçiçek, İstanbul, Huzur Yayınevi, 2011, s. 34.

17 İmam Nevevi, Riyazüs Salihin, terc. Mehmed Emre, c. I, İstanbul, Bedir Yayınevi, 1974, s.309. 
lebileceğini ifade etmektedir. ${ }^{18}$ Gayrimüslimlere sadakayı mubah kılmak üzere inen ilgili ayet, şu sosyal mesajı vermektedir:

Onları hidayete erdirmek sana ait değildir. Fakat Allah, dilediğini hidayete erdirir. Hayır olarak ne harcarsanız, kendiniz içindir. Zaten siz ancak Allah'in rızasını kazanmak için harcarsınız. Hayır olarak her ne harcarsanız-hiç hakkınız yenmeden-karşıllğ $\mathrm{l}$ size tastamam ödenir. ${ }^{19}$

Taberi, bu ayete şöyle bir yorum getirmektedir: Ey Muhammed! Müslüman olmayanların İslâm'a girmek suretiyle hidayet bulmaları senin üzerine borç değil ki onlara sadakaların verilmesine engel oluyorsun. İhtiyaçları olur da hiç değilse o yolla İslâm'a girerler diye sadakalardan onlara bir şey vermiyorsun. Yarattılarından dilediğinin İslâm 'a girerek, hidayet bulmasinı sağlayacak sadece O'dur. Bu sebeple onlara verilecek sadakayı engelleme. ${ }^{20}$

Ayetin nüzul sebebi ile ilgili olarak şunlar ifade edilmektedir: Müslümanlar, ilk dönemlerde yoksul zimmîlere de tasaddukta bulunuyorlardı. Zengin Müslümanların sayısının az ve fakir Müslümanların sayısının da fazla olmasından dolay1 Hz. Peygamber, kendi ümmetini düşünerek, Sadece kendi dindaşlarına tasaddukta bulunun şeklinde bir tavsiyede bulunmuştu. Ancak; Allah, Peygamberin bu tavsiyesini uygun bulmamış ve kendisine hemen ilgili ayeti göndermiştir. $\mathrm{Bu}$ ihtar mahiyetindeki ilahî mesaj üzerine Hz. Peygamber, zengin ve varlıklı Müslümanlara, tasaddukta bulunurken, diğer din mensuplarına bağl1 yoksul insanları da düşünmeleri gerektiğini hatırlatmıştır. Hz. Peygamber, bununla da yetinmeyip, sadaka (zekât) ve ganimetten kendi hissesine düşen paydan Müslüman olmayan yoksullara da vermiş ve bunun için tahsisatta bulunmuştur. ${ }^{21}$

Bununla birlikte Müslüman yoksullara maddî zararı ve beytü'l-mal'da yeterince kaynak sıkıntıs1 olmadığ1 sürece bedenî veya yaş durumu ne olursa olsun fakir zimmîlerin zekâttan bir pay alma hakkı olduğuna dair görüşler de kabul edilmektedir. Özellikle konu, muellefe-i kulup (kalpleri İslâm'a 1sındırılmak istenenler) bağlamında ele alındığında fakir zimmîlerin de zekâtın koruyucu şemsiyesi altına alınabileceği söylenebilir. ${ }^{22}$ Buna göre zekâttan yararlanabilecek sosyal

18 Kurtubi, El-Câmi'li-ahkâmi'l-Kur'an, 1962, s.337.

19 Kur'an-ı Kerim, Bakara (2): 272.

20 Muhibbuddin Ahmed b. Abdullah et-Taberî, Câmi'u'l-beyân, c. III, ty., s.94.

21 Saffet Köse, "Müslüman Düşüncesinde İnsanın İnsanlığı Sebebiyle Saygınlığının Zirve Noktas1-Gayr-i Müslimlere Yardımın Mali İbadet Kapsamında Oluşu”, İslam Hukuku Araştırmaları Dergisi, say1 14, 2009, s.54-55.

22 Raşid el Gannuşi, İslâm Toplumunda Vatandaşlık Hakları, terc. Abdülmecit Can, İstanbul, Birleşik Yayıncılık, 1996, s.142-143. 
kesimlerin belirlenmesi, korunmaya muhtaç kişilerin ihtiyaçları doğrultusunda ortaya çıkmaktadır. Bu konuda Ebu Hanife'nin şu ifadelerine yer vermekte fayda vardır: Sadakaların (Zekâtların) dağıtımında, yetki veliyyü'l emrin'dir (Müslüman devlet başkanınındır). Bazı (muhtaç) sosyal grupları diğerine tercihte bir sakınca yoktur. Ihtiyaçtan dolayl sadece bir sosyal gruba da harcanabilir. ${ }^{23}$

Buna göre bir İslâm ülkesinde yaşayan gayr-i Müslim yoksullara, temel ihtiyaçlarını karşılayabilecek bir hayat sürdürebilme hakkı verildiği anlaşılmaktadır. ${ }^{24}$

\section{Evsiz, Kimsesiz, Engelli ve(ya) Bakıma Muhtaç Yoksullar Olarak Miskinler}

Miskin ile aynı kökten gelen meskenet, horlanmak, küçük düşmek, sıkıntı içinde yaşamak ve yeteneklerden mahrum olmak anlamlarına gelmektedir. $\mathrm{Bu}$ bağlamda miskin, bugünün terminolojisi ile zelil (zihinsel ve ruhsal engelliler) ve bedenen zayıf kişiler (ortopedik engelliler) için de kullanılabilir. Dolayısıyla engelliler grubuna giren dezavantajlı sosyal kesimlerde bulunan özelliklerin, miskin kavramı içinde de yer aldığını söyleyebiliriz.

Arapçada miskin, "sükûnet" kelimesinden türediği için, aynı zamanda "hareket edemeyen" ve "oturup duran" anlamlarına da gelmektedir. Beled suresinin 16. ayeti de bu çerçevede değerlendirilebilir. Beled suresinin ayetleri Mekke'de indiği sıralarda Müslümanlar, müşriklerin kuşatması altında çok zor bir dönem yaşamaktaydılar.

İslâm'ın getirmiş olduğu sosyal hukuk sistemine dayalı bir devlet modeli henüz yoktu. Buna rağmen bu sure, engelleri aşmak için, Müslümanlara sosyal dayanışma içinde bulunmalarını emretmekte ve bu bağlamda kölelerin azat edilmesini, yetimlerin ve(ya) miskinlerin (gizli yoksulların) doyurulmasını tavsiye etmektedir. Miskine gelince ayet, "Ev miskînen zâ metrabetin” ifadesini kullanmaktadır. ${ }^{25}$ Turab, yani toprak üstünde olan bir miskin tabiri, miskin ve toprak arasında bir bağ oluşturulmuş olduğundan dolayı çok manidardır. Miskin, bu durumda yoksul olduğu için, sokakta yaşamak mecburiyetinde birakılan evsiz barksız bir kimse olabilir. Buna göre miskin, toprağa-sokağa atılmış, kalacak bir yurdu dahî olmayan terk edilmiş kimsesiz bir gariptir.

23 İmam Muhammed, Kitabu'l Hucce Ala Ehli'l Medine, thk. Mehdî Hasan Şahcihanpûrî, c. 1, Lahor, 1981, s.495.

24 Burada miskin kapsamında değerlendirilen Gayrî-Müslim yoksullara yönelik nakdî yardımın finansmanının zekât mı veya diğer kaynaklardan mı sağlanacağı yönündeki fikhî tartışmalara girilmemiştir. Vurgulanmak istenen konu, hangi dinden olursa olsun bütün yoksulların İslâmî sosyal koruma sisteminin altında olduğudur.

25 Kur'an-ı Kerim, Beled (90): 16. 
Miskinlik, acizlik ve zillet bağlamında ele alındığında yoksulluktan daha aşağı ve farklı bir durumdur. ${ }^{26}$ Nitekim yoksulluğa ve sürekli açlığa bağlı olarak bir kimse, aciz duruma düşer, bedenen zayıflar, ihtiyaçlarını artık kendi gayretiyle karşılayamaz, yerinde bedenen sâkin (hareketsiz) kalır, bitap düşmekten dolayı toprağın üzerinde uzanmanın ötesinde bir şey yapamaz hâle gelir. Bu durumda kişi elde olmayan sebeplerle miskin durumuna gelebilmektedir. Örneğin yetim bir çocuk eğitim sürecini tamamlayıp iş buluncaya ve(ya) iş kuruncaya kadar ihtiyaç sahibi bir miskin olabileceği gibi, hasta bir insan iyileşinceye kadar ve(ya) bakıma muhtaçlık durumu ortadan kalkıncaya kadar miskin olarak düşünülmektedir. ${ }^{27}$

$\mathrm{Bu}$ durumda zekât gelirleri ile mutlak anlamda evi bark1 olmayan sokak insanlarının, çalışma gücünü yitirmiş çaresizlerin, işsizlerin, yaşlı ve engellilerin vb. grupların sosyal korunmaya alınması gerekmektedir. Herhalde aşırı fakirlik veya ileri derecede engellilik veya ihtiyarlık gibi bedenî ve zihni sarsan olağanüstü fizyolojik ve psikolojik durumlar, kişiyi çökertip bilinçsiz, hareketsiz ve başkalarına bağımlı bir duruma getirdiğinden dolayı böylesi düşkünlere miskin denilmiştir. Bu duruma düşmüş aciz insanlar, başkalarının fizikî ve maddî desteği olmadan hayatlarını idame ettiremezler.

Dolayısıyla bedenen veya zihnen belirli bir rahatsızlığ olan miskinler, başkalarına bağımlı hâle geldikleri için, aynı zamanda bakıma muhtaç kişilerdir. Bu itibarla bedenen hareketsiz hâle gelen ileri derecede engelli, kronik hasta ve(ya) yaşlı insanlar, hayatlarını idame ettirebilmek için, sadece maddî desteğe değil aynı zamanda başkalarının tıbbî, sosyal ve manevî bakım hizmetlerine de ihtiyaç duyarlar. Bu yönüyle miskinler grubuna, bakıma muhtaç kişiler de girmektedir. Bakıma muhtaçlara ve sürekli olarak bakım hizmetlerini üstlenen aile fertlerine zekât fonundan maddî destekte bulunmak, Kur'an-1 Kerim'in öngördüğü sosyal dayanışma ruhuna tamamen uygundur.

\section{Miskin ve Yoksullar Arasındaki Farklılıklar}

Günümüzde miskinlik ve yoksulluk kavramları arasında, her iki durumun da mahiyetinin tam olarak anlaşılamaması ve(ya) toplumsal düzeyde bu kavramlarla ilgili kalıplaşmış düşüncelerden dolayı net bir ayırımın olmadığı gözlemlenmektedir. Oysaki miskinlik ve yoksulluk birbirine karşıt durumlar olmadığı gibi aynı nitelikteki durumlar da değildir. Bu bağlamda yoksul ve miskin kapsam (içerik), bedeni durum, şahsi (kişilik) durum, ekonomik durum, yaşam koşulları ve top-

26 Elmalı M. Hamdi Yazır, Hak Dini Kuran Dili, c. 4, İstanbul, Azim Dağıtım, 2011, s.403.

27 İlmihal I, İman ve İbadetler, Ankara, Diyanet İşleri Başkanlığı, 1998, s.488. 
lumsal farkındalık açısından ele alındığında iki kavram/durum arasında bir takım farklilıklara rastlanmaktadir (Bkz. Tablo 1).

Miskinlik ve yoksulluk kapsam bakımından ele alındığında; yoksulluğun daha dar bir içeriğe sahip olduğu, miskinliğin ise yoksulluğun ötesinde birçok psiko-sosyal, kültürel ve ahlâkî unsurlar/meziyetler taşıdığı görülmektedir. Yani miskinler sahip oldukları güzel ahlâkı ileri derecede ortaya koyabilmeleri ile yoksullara önemli birer emsal teşkil edebilecek niteliğe sahiptirler. Diğer bir ifade ile miskinlerin maddî yetersizlikler kapsamında yoksul olduğunu ifade etmek mümkündür. Ancak bu durum her yoksulun miskin olduğunu doğrulamamaktadır.

Her iki durum bedeni açıdan ele alındığında miskin ve yoksul arasında yine bir takım farkl11ıkların bulunduğu görülmektedir. Bedeni bütünlüğü olsun ya da olmasın genel olarak tüm insanların yoksulluk riski ile karşı karşıya olduğu gözlenirken, miskinlik durumu ile çoğunlukla özel olarak korunması gereken (engelli, yaşl1, çocuk, vb.) güçsüz insanların karşılaştı̆̆ görülmektedir.

Miskin ve yoksullar bakımından bir diğer fark, şahsî durumdur. Miskinler, maddî yönden yaşadıkları muhtaçlık halini dışarıya yansıtmamaya çalışıp suskun bir duruş ortaya koyarlar. Bu bağlamda miskinler diğer insanların kendilerinde yardım etmesi çabasında da değillerdir. Yani niyetleri başkaları tarafından anlaşılmak ya da anlaşılmaya çalışmak da değildir. Bu durum sosyal hayatta miskinlerin fark edilmesini zorlaştırdığı gibi diğer insanların onları anlayabilmelerini de güçleştirmektedir.

Yoksullukta ise kişi kimi zaman çekingen tavırlar sergilemekle beraber durumunun yakın çevresi tarafından da bilinmesinin meydana getirdiği etki ile içinde bulunduğu durumu daha rahat ifade edebilmektedir. Bu durumda miskinlerin kişilik özelliklerinin onların ekonomik durumları ve yaşam koşullarını da şekillendirdiği görülmektedir. Yani miskinler yardıma muhtaç olup durumlarını ortaya koyamayan ya da koymayan kişilerdir. Bu durumdaki kişilerin belirlenebilmesi için derinlemesine yapılmış sosyal inceleme ve(ya) araştırmalara ihtiyaç vardır. Böylece miskin olduğu tespit edilen kişinin kim bilir belki de yoksuldan daha da muhtaç durumda olduğu anlaşılacaktır. 
Tablo 1: Miskin ve Yoksullar Arasındaki Temel Farklar ${ }^{28}$

\begin{tabular}{|c|c|c|}
\hline BOYUT & MíSKIN & YOKSUL \\
\hline $\begin{array}{l}\text { Kapsam } \\
\text { (İçerik) / } \\
\text { Maddî } \\
\text { Durum }\end{array}$ & $\begin{array}{l}\text {-Her miskin yoksuldur fakat } \\
\text { kendini muhtaç olarak görmez. } \\
\text {-Miskinlik, yoksulluğun sadece } \\
\text { bir boyutudur ve yoksulluk ötesi } \\
\text { farklı anlamlar taşır. }\end{array}$ & $\begin{array}{l}\text {-Her yoksul, yardıma muhtaçtır ve } \\
\text { yardım almaya hazırdır. } \\
\text {-Her yoksul miskin değildir. } \\
\text {-Yoksulluk miskinlikten daha dar } \\
\text { bir anlam ifade eder. }\end{array}$ \\
\hline $\begin{array}{l}\text { Bedeni } \\
\text { Durum }\end{array}$ & $\begin{array}{l}\text {-Engelli, yaşlı, bakıma muhtaç } \\
\text { durumdaki tüm gruplar. }\end{array}$ & $\begin{array}{l}\text {-Bedeni bütünlüğü olsun ya da } \\
\text { olmasın tüm gruplar. }\end{array}$ \\
\hline $\begin{array}{c}\text { Şahsi } \\
\text { (Kişilik) } \\
\text { Durum }\end{array}$ & $\begin{array}{l}\text {-Çekingen, sessiz, kendini ifade } \\
\text { etmede isteksiz, suskundur. } \\
\text { - Yoksulluğunu gizler. } \\
\text { - Miskinler, onurlu bir yaşam } \\
\text { kültürünü yansıtmaktadır. }\end{array}$ & $\begin{array}{l}\text {-Çekinmeden derdini başkalarına } \\
\text { anlatır. } \\
\text {-Yoksulluğunu teşhir eder ve bu } \\
\text { durumdan rahatsızlık duymaz. } \\
\text {-Yoksullar, yoksulluk kültürünün de } \\
\text { kurbanı olabilir. }\end{array}$ \\
\hline $\begin{array}{c}\text { Ekonomik } \\
\text { Durum / } \\
\text { Yaşam } \\
\text { Koşulları }\end{array}$ & $\begin{array}{l}\text { =Yardım talep edemez. } \\
\text {-İş bulmak için gayretlidir. } \\
\text {-Müstakil bir hayat için } \\
\text { onuruyla mücadele eder. }\end{array}$ & $\begin{array}{l}\text {-Yardım talep eder. } \\
\text {-Bazıları iş aramada gevşeklik } \\
\text { gösterebilir. } \\
\text {-Başkalarının yardımına muhtaç } \\
\text { olduğunu düşünerek, kendini } \\
\text { bağımlı hisseder. }\end{array}$ \\
\hline $\begin{array}{c}\text { Toplumsal } \\
\text { Farkındalık }\end{array}$ & $\begin{array}{l}\text {-Miskinlere yönelik toplumsal } \\
\text { farkındalık düşüktür. } \\
\text {-Feraset sahibi kişiler, } \\
\text { miskinlerin özel durumunu } \\
\text { görebilir. }\end{array}$ & $\begin{array}{l}\text {-Yoksullara yönelik toplumsal } \\
\text { farkındalık yüksektir. } \\
\text {-Herkes, yoksulların durumunu } \\
\text { kolaylıkla gözlemleyebilir. }\end{array}$ \\
\hline
\end{tabular}

Miskin ve yoksulların temel özelliklerinden hareketle açıklanmaya çalışılan farklılıklar, aslında iki durumun özellikle maddî yetersizlikler boyutuyla birbirine çok yabancı olmadığını gösterirken, bir o kadar da ikisi arasında görülmesi, fark edilmesi incelik gerektiren ayrılıkların da olduğuna işaret etmektedir. $\mathrm{Bu}$ inceliğin merkezini miskinin utancından isteyememesi niteliği oluşturmaktadır.

28 Ali Seyyar, Ahlâk Terimleri Ansiklopedik Sözlük, İstanbul, Beta Yayınları, 2003, s.298-299; The New York Times, “The Unseen Poor”, December 21 1884, Mart 2018, (http:/query.nytimes.com/gst/abstract.html?res=9805EFD91339EF34BC4C51DFB7678388669FDE), Gino Fanelli, “The Invisible Poor”, Mart 2018, (http://reporter.rit.edu/features/invisible-poor)'dan faydalanılarak yazar tarafından oluşturulmuştur. 


\section{Modern Dönem Miskinlik Olgusu}

Görüldügüü üzere miskinler bugünün halk anlayışına göre uyuşuk, tembel zavallı kişiler olarak algılansa bile bu yaygın inanışın aksine miskinler ne uyuşuk, ne tembel ne de zavallı insanlardır. Batı dünyası da geç de olsa bu nitelikte olan yoksulları sosyal yardım politikaları sonucunda fark edebilmiş durumdadır. Çalışmanın başında da ifade edildiği gibi miskinler şahsî özelliklerinden dolayı ulaşılması, fark edilmesi zor kişiler olarak anılmaktadırlar. Onun için Batı kaynaklarında miskinler, Kur'an-1 Kerim'in vermek istediği anlama yakın bir biçimde genelde sessiz yoksullar (silent poor) bazen ise gizli, görülmeyen veya duyulmayan yoksullar (secret, unseen and unheard poor) olarak ifade edilmektedir. ${ }^{29} \mathrm{Bu}$ çerçevede miskinler, ne refah hırsızlığı yapan, ne de toplumsal kurallara aykırı davranışlarda bulunan insanlardır. Çünkü bu yaklaşım, miskinleri incitmekten ve onları maddî ve manevî çıkmazlara sürüklemekten, toplumu karmaşaya itmekten başka bir amaca hizmet etmemektedir. ${ }^{30}$

Burada akla şu soru gelmektedir. Dilenmekten çekinmeyen ve çekinen yoksulları ayırmak rasyoneldir ve gündelik hayatta bu husus gözlemlenebilmektedir. Ancak bunları bir bütün olarak yoksulların içinden ayıracak kriterlerimiz neler olacaktır? İşte bu sorunun cevabını araştırmalar neticesinde ortaya koyabilmekteyiz. Bilimsel/sosyolojik araştırmalara dayalı olarak oluşturulacak sosyal sorumluluk politikalarının adaletli uygulanması neticesinde yoksul-miskin ayırımını yeterince yapmak mümkün gözükmektedir.

Örneğin, İngiltere'de yapılmış çalışmalar, miskinlik riski ile karşı karşıya olabilecek kişilerin kimler olduğunu açıklaması, böylelikle miskinlik ve miskinler ile ilgili çalışmalarda daha çok hangi gruplara odaklanılması gerektiğini ortaya koyması bakımından önem teşkil etmektedir. Bu çalışmalara göre cinsiyet eşitsizliği tıpk1 yoksullukta olduğu gibi miskinlik üzerinde de doğrudan bir etki oluşturmazken, miskinlik riskini arttırmada ise önemli bir faktör olarak görülmüştür. Bu kapsamda kadınların ya da erkeklerin aile içi eşitsizliklere uğramaları nedeni ile mirastan daha az pay almaları, bu durumu toplum tarafindan ayıplanmamak ve dışlanmamak için başkalarına anlatmak istememeleri, özellikle kadınları miskinlik riski (sessizliğe mahkûmiyet tehlikesi) ile karşı karşıya bırakan önemli bir faktör olarak açıklanmıştır. Bunun yanı sıra dulluk-boşanma (genelde eşlerini kaybeden ve evlilik öncesi çalışmamış olup eşinden boşanan yaşlı kadınlar için), hiç evlenmemiş kişiler (gençlik döneminde para idaresi-tasarruf alış-

29 The New York Times, a.g.e.

30 ATD Fourth World, "The unheard voices of people in poverty International Human Rights Day - December 10th 2012", Ekim 2015, (http://atd-fourthworld.org/the-unheard-voices-ofpeople-in/). 
kanlığı kazan(a)mamış yaşlı kadınlar ve çoğunlukla yaşlı erkekler için) miskinlik riski bakımından üzerinde durulması gereken gruplar olarak görülmektedir. Ayrıca yaşlılık döneminde boşanmış olan kadınların hiç evlenmemiş kadınlara göre miskinlik riskine daha fazla sahip olduğu da ortaya konmuştur. ${ }^{31}$

$\mathrm{Bu}$ çalışmalar, genellikle cinsiyet ve yaş temelinden hareketle miskinlik riskini ele almış olmakla birlikte; yoksul aileler içerisinde büyüyen, eğitim ve sağlık açısından gerekli desteği göremeyen çocukların-gençlerin, işini kaybetmişlerin, iflas etmişlerin, çalışamayacak derecede engelli olan kişilerin, sağlik sorunları yaşadıktan sonra emek piyasasına dönmek isteyen ancak hastalığın etkisi ile fizyolojik bir takım değişiklikler yaşayan ve bu sebeple toplumdan dışlanan kişilerin, göçmenlerin, eski hükümlülerin vb. özel grupların da miskinlik (korunmaya muhtaçlık) riski kapsamına girme olasılıklarının yüksek olduğu unutulmamalıdır. $\mathrm{Bu}$ sebeple miskinlere yönelik koruma ve yapılacak yardımlarda öncelikle araştırmalar sayesinde gün yüzüne çıkmış olan bu gruplar üzerinde odaklanmak ve onlara ulaşmaya çalışmak önem taşımaktadır. Ancak bunu yaparken de dini, dili, cinsiyeti, yaşı ne olursa olsun ayrım gözetmemek sosyal korumayı ve yardımı gösteriş yaparcasına uygulamamak önem taşımaktadır.

Bu durumda kaynakların adil dağılmamasına bağlı olarak miskinin kimi zaman küçük bir çocuk, engelli, işsiz ya da çalışan, yaşlı veya genç, dul bir kadın, hiç evlenmemiş bir erkek olabildiği görülürken, kimi zaman da bir göçmen, sığınmacı ve mültecinin miskin olabileceği hatırda tutulmalıdır. ${ }^{32} \mathrm{Bu}$ durumda miskinleri kapsam olarak tam anlamı ile sınırlandırmak da mümkün görünmemektedir. Çünkü miskinlik, yoksulluğun görünmeyen yüzü olup içinde zikredilmeyen ve belki de tahmin edilemeyen daha nice kesimleri barındırmaktadır. ${ }^{33}$ Miskinlerin bu denli geniş bir kitleyi içermesi, sosyal yaşamın düzenlenmesinde etkili olan tüm aktörleri, özellikle de dinî müesseseleri miskinleri bulmada ve onlara yönelik sosyo-ekonomik ve psiko-sosyal sorunları çözümlemede önemli birer araç ve potansiyel haline getirmektedir. Zaten yoksulluk araştırmalarında da esas mesele hak eden yoksula ulaşmak olmalıdır.

31 Fran Bennett - Mary Daly, "Poverty through a Gender Lens: Evidence and Policy Review on Gender and Poverty", University of Qxford Department of Social Policy and Intervention, 2014, s. 27; Dieter Demey- Ann Berrington- Maria Evandrou- Jane Falkingham "Pathways into living alone in mid-life: diversity and policy implications", Advances in Life Course Research,18, 2013, s. 163.

32 Bennett ve Daly, a.g.e., s. 27-28.

33 John Doyle, "Poverty is All Around, So How Does It Go Unseen by Us?”, Ekim 2015, (http:// www.theglobeandmail.com/arts/television/poverty- is-all-around-so-how-does-it-go-unseenby-us/article5442354/). 
Ayrıca bu kişileri korumak demek onlara sadece maddî yönden finansal aktarımlarda bulunmak anlamını da taşımamaktadır. Miskinlerin temel gereksinimlerini karşılayamamanın getirdiği yokluk duygusu yanında, çaresizlik, yarınından emin olamama ve umutsuzluk durumu içerisinde de oldukları görülmektedir. $\mathrm{Bu}$ durumda miskinlere sağlanacak maddî korumanın yanında eş zamanlı olarak sağlanacak sosyal ve manevî destekler de önemli birer araç olarak nitelendirilmektedir.

$\mathrm{Bu}$ bağlamda hangi toplum ve kültür olursa olsun gizli yoksul olarak tanımlanan miskinlerin bilinen yoksul ve yoksulluk algısının dışında arka planda kaldığı görülmektedir. Diğer bir ifade ile miskinliğin yoksulluğun en can acıtıcı ve derin boyutu olduğunun henüz tam manası ile kavranamamış olması, miskinleri korumaya yönelik önlemlerin önündeki en büyük engeldir.

\section{Sonuç}

Sosyal bilimlerin gelişmesiyle birlikte sosyal güvenlik sistemlerinin önemsendiği küresel dünyamızda yoksul ve miskinlerin konumlarının çağın ihtiyaçlar1 doğrultusunda yeniden belirlenmesine ihtiyaç vardır. Kur'an-1 Kerim'de ayrı ayrı zikredildiğine göre bu iki grubun arasında benzerliklerin yanında yukarıda açıklandığı gibi bazı farklılıkların da bulunması gerekmektedir. Tespitlerimize göre bu farklılıklar, maddî yetersizlik meselesinin ötesinde daha çok ahlâk-karakter-mizaç ve bedenî-fizikî yapı gibi kişiye özel alanlarda kendini göstermektedir. İslâm'ın evrensel sosyal koruma sistemi açısından önemli olan, hangi din veya inanç sisteminden olursa olsun yardıma, desteğe ve bakıma muhtaç bütün insanların temel ihtiyaçlarının giderilmesine yönelik olarak sosyal dayanışma ve hizmet kurumlarının oluşturulmasıdır.

$\mathrm{Bu}$ bağlamda sosyal dayanışma duygusu ile sosyal korumayı geliştirmek ve yaygınlaştırmak isteyen toplumların yoksullara ve gizli yoksul olarak nitelendirilen miskinlere yardımda ve korumada devamlılık ilkesi gereği kurumsal boyutta sahip çıkması gerekmektedir. Böylelikle sosyal dışlanma riskinin meydana getireceği sosyal karmaşaların önüne geçilmiş olunacak ve birlik duygusu içerisinde daha sağlıklı bir toplumsal yapının inşası sağlanacaktır. Aslında bu süreçte birer (gizli) yoksul olarak nitelendirilen miskinleri bulmak ve onlara ulaşmak da görüldüğü ve düşünüldüğü kadar kolay değildir. Çünkü miskinler bilinen yoksulluğun ve yoksulların aksine kimi zaman toplum tarafindan fark edil(e)meyen, kimi zamanda fark edilmemek isteyen, çoğunlukla durumlarından haberdar olunamayan kişilerdir. Bu sebeple bu kişileri tespit etmek, onlara ulaşmak ve çok geç kalmadan yardımda bulunmak sadece belirli kurum ve kuruluşlara değil toplumun tamamına atfedilen bir görev olmalıdır. 
Yoksulluk ve miskinliğin farklı boyutlara sahip olması yoksul ve miskinlere sağlanacak yardımları ve bu yardımların ulaştırılma türünü de değiştirmektedir. Günümüzde yoksullara sağlanan sosyal yardımların büyük bir çoğunluğu kamusal sosyal yardımlar adı altında kurumsal boyutta sağlanmakta ve yoksullar bu şekilde sosyal korumaya alınmaktadır. Ancak bu grup, yoksulluğun ve yoksulların görünen yüzünü temsil etmektedir. Oysaki görünenin ardında kalarak giderek sessizleşen yoksullar da toplumsal açıdan korunmayı hak etmektedirler. Nazenin yapıları ve giderek artan sayıları ile sessiz yoksullar olarak da adlandırılan miskinler, özel olarak korunması, kollanması ve toplumla bütünleştirilmesi gereken sosyal gruplardır. Böylelikle, muhtaçlık devam ettiği sürece bu kişilere yapılan yardımların sürmesi, buna karşın bu hassas ruhlu kişileri incitmeyecek ve yoksulluğu teşvik etmeyecek en uygun yöntemin seçilmesi, uygulanması, geliştirilmesi ve devamlılığının sağlanması miskinleri korumada esas alınmalıdır.

Miskinlere yönelik sosyal korumada modern sosyal güvenlik uygulamalarına ek olarak, geleneksel sosyal güvenlik uygulamalarının da yeniden gözden geçirilerek kurumsal boyut kazanması önem taşımaktadır. Bu uygulamalar kapsamında zekât kurumu devamlılık içermesi bakımından önemli bir sosyal koruma yöntemi olarak düşünülmektedir. Zenginden fakire zekât yolu ile yapılacak transferlerin sosyal adalet kapsamında gelirin yeniden dağılımına pozitif bir etki oluşturması beklenmektedir. Bu uygulama ile miskinlere yönelecek olan transferlerin, miskinleri içinde bulundukları maddi, sosyal, tıbbi ve mânevi sıkıntılardan kurtarması beklenmektedir. Miskinlerin gelirlerinin artışı ise tüketimi arttıracak, tüketim artışı ise yeni yatırımları uyaracaktır. Böylece artan yatırımlarla yoksul ve miskinlerin çalışabilir durumda olanlarının aktif olarak topluma kazandırılması sağlanırken, çalışamayacak durumda olanlar ise gelir kayıpları ve gider artışına bağlı risklerden sosyal transferle uzaklaşacaklardır. ${ }^{34}$

Bu kapsamda zekâtın toplanması ve ihtiyaç sahiplerine ulaştırılması kimi zaman dernek vb. gönüllü kuruluşlar kapsamında da gerçekleştirilmekle beraber, bu kuruluşların bir kısmının kısa süre faaliyet göstermesi, yeteri kadar kurumsallaşamamaları veya toplumun güvenini kazanamamaları zekâtın bu kurumlar vasıtası ile muhtaç durumda olanlara ulaşmasını engellemektedir. Bu durumda toplumun güvenini temin edecek, kurumsallaşmış, devamlılık içeren devlet çatısı altında bir sistemin oluşturulması ile ihtiyaç sahibi miskinlerin korunması sağlanabilecektir. Ancak bu sosyal bölüşüm sürecinde en büyük sorun miskinlerin, diğer bir deyişle görünmeyen yoksulların nasıl bulunacağı ve onların zekât müessesesin- 
den nasıl faydalandırılacağıdır. İslam dininin bir elin verdiğini öbür elin görmemesi yaklaşımından hareketle zekâtın kurumsal bir boyut kazanması ve kişileri incitmeksizin onların yaralarını maddi ve mânevi olarak sarmaya çalışması önem taşımaktadır.

$\mathrm{Bu}$ durumda zekâtı kurumsal hale getirmek için Diyanet İşleri Başkanlığı, Aile ve Sosyal Politikalar Bakanlığı ve ilgili diğer bakanlıklar işbirliğinde zekâtın toplanması ve dağıtımından sorumlu birimlerin kurularak "Ulusal-Kamu Zekât Fonu" adı altında kurumsallaşmış bir fon oluşturulmalıdır. Böylece toplanan zekâtların ayrı bir havuzda biriktirilmesi, bunun devlet tarafından şeffaf bir şekilde yapılması, yardımların yerine ulaştığına yönelik inancın artması ile devamlılık kazanan bir sistemin oluşması sağlanmalıdır. Ayrıca bu süreçte miskinlerin tespit edilebilmesi için sivil toplum, yerel aktörler ve devlet arasında işbirliği de geliştirilmelidir. Miskinlere aktarılacak yardımları onlara elden ve doğrudan yardım adı altında ulaştırmak yerine bu kişileri deşifre etmeden ve(ya) eğer mümkünse onların emeklerinden faydalanarak ve onları yetenekleri ve uğraşlarına göre bir şeyler üretmeye teşvik ederek, farklı isimlerle bir takım ödemelerde bulunmak gerekmektedir. Böylece miskinler onurları zedelenmeden kişilikleri ile topluma daha faydalı hâle gelebileceklerdir. Netice itibariyle miskinlik olarak ifade edilen gizli yoksulluğun dünyanın ortak bir sorunu haline gelmesi nedeni ile miskinlerin sosyal refahını sağlamada tüm sosyal müesseselerin ahenkli bir biçimde ve adeta görünmeyen bir el gibi çalışması gereklilik arz etmektedir. 


\section{Kaynakça}

Ağırman, Cemal, "Yoksullukla Mücadelede Ahlaki ve Dini Eylem Olarak İnfakın Rolü”, Yoksulluk Sempozyumu, ed. Ahmet Emre Bilgili, İbrahim Altan, İstanbul, Deniz Feneri Yayınları, 2003.

Aksan, Gamze, "Yoksulluk ve Yoksulluk Kültürünün Toplumsal Görünümleri”, Selçuk Üniversitesi Sosyal Bilimler Enstitüsü Dergisi, sayı 27, 2012.

Aktaş Beytullah, "Zekâtın Harcama Kalemlerinden Fakir ve Miskin Kavramlarının Kur'an Bağlamında Yeniden Tanımlanması”, Harran Üniversitesi İlahiyat Fakültesi Dergisi, y1l 20, sayı 33, Ocak-Haziran 2015.

Altıntaş, Hayrani, Tasavvuf Tarihi, Ankara, Ankara Üniversitesi İlahiyat Fakültesi Yayınları No: 190, 1991.

ATD Fourth World, "The unheard voices of people in poverty International Human Rights Day - December 10th 2012", Ekim 2015, (http://atd-fourthworld.org/the-unheard-voices-of-people-in/).

Bennett, Fran - Daly, Mary, "Poverty through a Gender Lens: Evidence and Policy Review on Gender and Poverty", University of Qxford Department of Social Policy and Intervention, 2014.

Demey, Dieter - Berrington, Ann -Evandrou, Maria - Falkingham, Jane., "Pathways into living alone in mid-life: diversity and policy implications", Advances in Life Course Research, 18, 2013.

Doyle, John, "Poverty is all around, so how does it go unseen by us?", Ekim 2015, (http://www.theglobeandmail.com/arts/television/poverty-is-all-aroundso-how-does-it-go-unseen-by-us/article5442354/).

Ebu Davud, Sünen-i Ebu Davud, İstanbul, Şamil Yayınları, 2009.

Ekşi, Ahmet, “Hz. Ömer'in "Miskin” Kavramıyla Zekât Uygulamalarına Getirdiği Açılım”, Mart 2019, (http://akademikpersonel.kocaeli.edu.tr/ahmet.eksi/ toplanti/ahmet.eksi02.10.2017_09.18.13toplanti.pdf).

el Gannuşi, Raşid, İslâm Toplumunda Vatandaşlık Hakları, terc. Abdülmecit Can, İstanbul, Birleşik Yayıncılık, 1996.

Es-Sâbûnî, Muhammed Ali, Safvetü 't-Tefâsîr, çev. Nedim Yılmaz, Sadreddin Gümüş, c. 2, İstanbul, Ensar Yayınları, Ağustos, 2012.

et-Taberî, Muhibbuddin Ahmed b. Abdullah, Câmi'u'l-beyân, c. III, ty.

Eyüpoğlu, Osman - Düzenli, Muhittin, "Yoksulluk ve Dini Hayat", Uluslararası Orta Asya Sempozyumu Bildiriler Kitabı Göç, Yoksulluk ve Kimlik, Bişkek, Kırgızistan-Türkiye Manas Üniversitesi Yayınları, 17-20 Nisan 2018. 
Fanelli, Gino, “The Invisible Poor”, Mart 2018, (http://reporter.rit.edu/features/invisible-poor).

İlmihal I, İman ve İbadetler, Ankara, Diyanet İşleri Başkanlığı, 1998.

İmam Muhammed, Kitabu'l Hucce Ala Ehli'l Medine, thk. Mehdî Hasan Şahcihanpûrî, c. 1, Lahor, 1981.

İmam Nevevi, Riyazüs Salihin, terc. Mehmed Emre, c. I, İstanbul, Bedir Yayınevi, 1974.

İslâm Ansiklopedisi, c. 30, İstanbul, Türkiye Diyanet Vakf1, 2005.

Köse, Saffet, "Müslüman Düşüncesinde İnsanın İnsanlığı Sebebiyle Saygınlığının Zirve Noktası-Gayr-i Müslimlere Yardımın Mali İbadet Kapsamında Oluşu", İslam Hukuku Araştırmaları Dergisi, sayı 14, 2009.

Kur'an-ı Kerim Meali, haz. Halil Altuntaş, Muzaffer Şahin, 11. baskı, Ankara, Diyanet İşleri Başkanlığı Dini Yayınlar Dairesi Başkanlığı, 2011.

Kurtubi, El-Câmi'li-ahkâmi 'l-Kur'an, 1962.

Molla Camî, Evliya Menkıbeleri, (Nefahat'ül Üns Min Hadarat'il Kudüs), sadeleştiren Abdulkadir Akçiçek, İstanbul, Huzur Yayınevi, 2011.

Seyyar, Ali, Ahlak Terimleri (Ansiklopedik Sözlük), İstanbul, Beta Yayınları, 2003. y1nları, 2002. , Sosyal Siyaset Terimleri Ansiklopedik Sözlük, İstanbul, Beta Ya-

Taşc1, Faruk, Sosyal Politika Ahlâkl, Ankara, Nobel Yayıncılık, 2012.

The New York Times, “The Unseen Poor”, December 21 1884, Mart 2018, (http://query.nytimes.com/gst/abstract.html?res=9805EFD91339EF34BC4C51DFB7678388669FDE)

Yazır, Elmalı M. Hamdi, Hak Dini Kuran Dili, c. 4, İstanbul, Azim Dağıtım, 2011.

Zaim, Sabahattin, "Zekâtın İktisadi Önemi”, İ.Ü. İktisat Fakültesi Maliye Araştırmaları Merkezi Konferansları Prof. Dr. Bedi N. Feyzioğlu’na Armağan, say1 35, 1992. 